\title{
Not walking? An uncommon spinal pathology
}

\author{
Manisha Ramphul, Kavita Chawla
}

Department of Paediatrics, Lister Hospital, East and North Hertfordshire NHS Trust, Stevenage, UK

\section{Correspondence to} Dr Manisha Ramphul, manisha.ramphul@nhs.net

Accepted 31 October 2015
CrossMark

To cite: Ramphul M, Chawla K. BMJ Case Rep Published online: [please include Day Month Year] doi:10.1136/bcr-2015213057

\section{DESCRIPTION}

A 14-month-old boy, independently mobile for 1 month, presented after refusing to walk for 2 days. He was afebrile, with no preceding coryzal illness. A diagnosis of transient synovitis was made. Owing to the lack of improvement and ongoing symptoms for 5 weeks, he underwent blood tests, which showed a $\mathrm{C}$ reactive protein of 7 , an erythrocyte sedimentation rate of 38 and a platelet count of 511.

Apart from the inability to weight bear, he was systemically well in himself. Septic arthritis, osteomyelitis ${ }^{1}$ and leukaemia were deemed unlikely diagnoses. Serial blood tests showed static infection markers. A pelvic X-ray and an ultrasound of the hips were unremarkable.

In view of the possible hip pathology, the child was booked for an MRI of his pelvis, with a plan

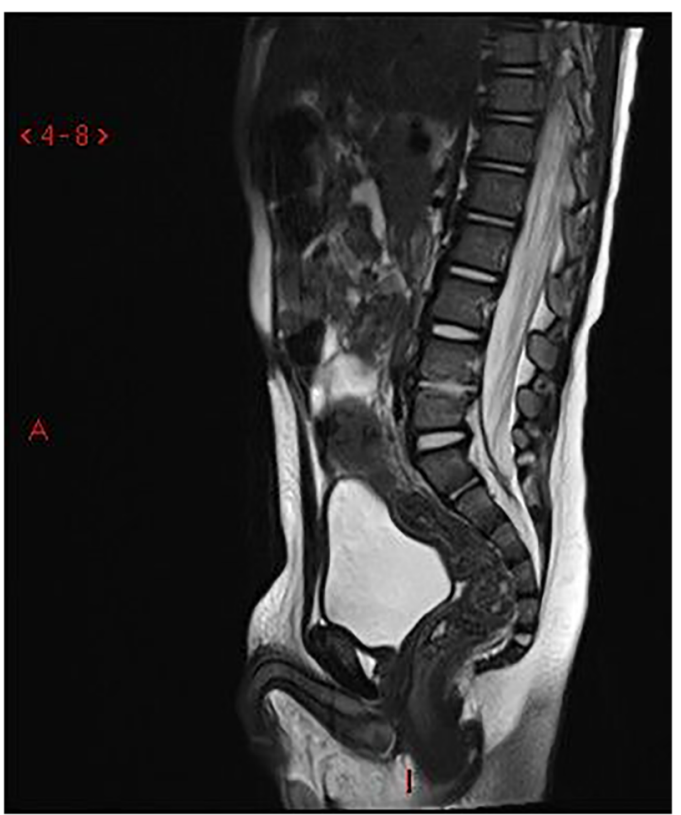

Figure $1 \mathrm{MRI}$ of the spine showing an ill-defined disc at L4-L5. to include the spine if the oral sedation lasted long enough. The spinal MRI showed L4/L5 discitis (figure 1).

Forty-eight hours into intravenous flucloxacillin, he started walking again. His blood cultures were negative. He continued on intravenous antibiotics for 6 weeks.

Discitis was not in our top differentials. It is an uncommon disease in toddlers. It is believed to be of infectious aetiology with the haematogenous transfer of the causative organism (most likely Staphylococcus aureus) to the disc space, despite sterile blood cultures. ${ }^{2}$ Management involves immobilisation and antibiotic therapy. ${ }^{3}$ It is a selflimiting illness, but awareness of this condition must be raised, with the aim of facilitating its diagnosis and management.

\section{Learning points}

- In a limping child, remember to assess for spinal pathology.

- A spinal MRI is the investigation of choice for discitis.

- Treatment of discitis entails a prolonged course of antibiotics, even in the presence of negative blood cultures.

\section{Competing interests None declared.}

Patient consent Obtained.

Provenance and peer review Not commissioned; externally peer reviewed.

\section{REFERENCES}

1 Fernadez M, Carrol CL, Baker CJ. Discitis and vertebral osteomyelitis in children: an 18-year review. Paediatrics 2000;105:1299-304.

2 Brown $R$, Hussain $M$, McHugh $K$, et al. Discitis in young children. J Bone Joint Surg Br 2001;83:106-11.

3 Lim S, Sinnathamby W, Noordeen H. Refusal to walk in an afebrile well toddler. Postgrad Med J 2002;78:568-70.

Copyright 2015 BMJ Publishing Group. All rights reserved. For permission to reuse any of this content visit http://group.bmj.com/group/rights-licensing/permissions.

BMJ Case Report Fellows may re-use this article for personal use and teaching without any further permission.

Become a Fellow of BMJ Case Reports today and you can:

- Submit as many cases as you like

- Enjoy fast sympathetic peer review and rapid publication of accepted articles

- Access all the published articles

- Re-use any of the published material for personal use and teaching without further permission

For information on Institutional Fellowships contact consortiasales@bmjgroup.com

Visit casereports.bmj.com for more articles like this and to become a Fellow 